\title{
Hydrogeological Recognition by Geoelectric Prospecting in the Ras Jerry Region. Basin of the Saïss Morocco
}

\author{
Salahddine Didi ${ }^{1}$, Humberto Bracamontes del Toro ${ }^{2, *}$, Fatima Ezzahra Housni ${ }^{3}$, Abdessamad Najine ${ }^{1}$ \\ ${ }^{1}$ Sultan Moulay Slimane University, Beni Mellal, Morocco \\ ${ }^{2}$ National Techology of Mexico Campus Cd. Guzmán. Cd. Guzmán Jalisco, México \\ ${ }^{3}$ Research Center in Food Behavior and Nutrition, University Center of the South \\ *Corresponding author
}

\begin{abstract}
A geophysical study based on 49 electric holes with a long line length (up to $4 \mathrm{~km}$ ) was carried out in the southwestern part of the plateau of Meknès (Morocco). This is located between the Rif to the north and the Middle Atlas to the south. The plateau of Meknes contains two main aquifer formations: the groundwater of the Plio-Quaternary and the deep layer of the Lias. The quantitative interpretation of the electric soundings, the geological data and the description of the drillings made it possible to draw isoresistivity and isopaque maps. These maps helped to better understand the hydrogeological structure of the region from a quantitative and qualitative point of view.
\end{abstract}

Keywords: Plateau of Meknes, geophysics, Plio-quaternary, isoresistivity, isopaque

Cite This Article: Salahddine Didi, Humberto Bracamontes del Toro, Fatima Ezzahra Housni, and Abdessamad Najine, "Hydrogeological Recognition by Geoelectric Prospecting in the Ras Jerry Region. Basin of the Saïss Morocco.” Journal of Geosciences and Geomatics, vol. 5, no. 4 (2017): 205-217. doi: 10.12691/jgg-5-4-5.

\section{Introduction}

Water is one of the major problems of countries on the southern shores of the Mediterranean, as it is a key limiting factor in sustainable development, improving the quality of life and peace. The quantitative and qualitative management of ground and surface water resources is currently a necessity, considering, on the one hand, the continuing increase in needs and, on the other hand, the degradation observed during the last decades in water quality in developing countries. Moreover, when resources are limited and the drought that affects the whole country becomes cyclical, this need becomes urgent. The MeknesTafilalt Economic Zone is a region characterized by significant human and agricultural activity. The increase in population and agro-food development experienced by the region in recent years have increased water demand. In addition, the recharging of the reservoirs is very weak because of the lack of effective rainfall, which has led the competent authorities to combine efforts to prospect, develop and develop new aquifers that could fill the water deficit. During these considerations, we hope to make a useful contribution by studying the hydric potential of the Ras Jerry region by applying geophysical methods as well as non-destructive recognition. This study is carried out based on 49 soundings distributed in a uniform manner. The objective of the study is to highlight the spatial variation of the surface aquifer, to follow the substrate constituted by marly formation of the Miocene and to specify their geometries to obtain the geological and hydrogeological model of the region.

\section{Study Area Context}

\subsection{Geographic and Geomorphological Context}

The study area is part of the Meknes-Fez basin, which covers an area of approximately $2200 \mathrm{~km} 2$ and occupies a large part of the Sebou watershed. It is bounded to the north by pre-riferous wrinkles and to the south by the outcrops of the Middle Atlasic Causse. To the west, it extends to the tributaries of the Oued Beht which separates it from the Zemmour-Maamora region and to the east it is bounded by the valley of the Oued Sebou.

A topographically straightforward accident, with a global East-West orientation, called Ain Taoujdat's flexure, clearly has two levels: The Meknes Plateau or the Western Saïss in the West and the Saïss Plain or the Eastern Saïss in the East [1]. The altitude of the plateau of Meknes decreases generally from south to north with an average slope of $12 \%$. It goes from $900 \mathrm{~m}$ in the region of El Hajeb to $550 \mathrm{~m}$ in Meknès [2]

\subsubsection{Geological Setting}

The Saïss basin corresponds to an intra-mountainous continental basin which is filled by deposits of superior Miocene-Quaternary age covering a Mesozoic and Paleozoic basement. Lithostratigraphic basin is summarized from the bottom up as follows:

Primary: The Paleozoic basement is exposed in the zone of Central Hercynian Morocco where it is in direct contact on a large space with the basin to the south. It is 
represented by some monotone facies of fine schists and quartzite with intercalation of sandstone beds, layers of sandy limestone to brachiopods and basic conglomerates. This base collapse and extends to the north under the Mesozoic and Neogene deposits of the Saïss basin and the pre-rifal wrinkles where it was sometimes reached by soundings made in the basin [3]

Triassic: Consisting mainly of gypsiferous and saliferous clays (evaporate deposits) with intercalations of doleritic basalts. These Triassic facies exist but very locally especially in the region of Khemisset (valley of Oued Beht) and present a variable thickness throughout the basin. It can reach $987 \mathrm{~m}$ [4].

Lias: The Lower Lias (Lotharingian) is mainly exposed to the south in the middle atlas. It constitutes the essential material of the reliefs with massive and ruiniform lower dolomitic limestones [3]. Medium Lias (Domerian and Carixian) is formed by cephalopod limestone at the top, then limestone and flint limestone. The thickness of these formations found in certain boreholes can reach $280 \mathrm{~m}$ (region of Sebâa-Ayoun). The depths of these formations are increasing in size from south to north.

Miocene: The Tortonian begins with some facies of sandy limestone with marlous passes whose thickness can reach a dozen meters. Above these facies there is developed a powerful series of gray marls, the thickness of which increases from south to north. It reaches $1000 \mathrm{~m}$ at the Douyet survey [5]. At the Mesosinian, the Miocene in the area ends with gray marls, sandy marls and sometimes marls with sandy intercalation of the Messinian. To the north of the basin this Messinian formation rests on the marls of the Tortonian with a detritic level at the base.

Pliocene. Lower Pliocene facies are generally sandy with carbonate matrix sands. These facies can reach a thickness of 50 to $80 \mathrm{~m}$ [6]. The lower Pliocene formations show lateral variations towards the eastern part of the basin, where they diminish in thickness until disappearance near the city of Fez. The middle Pliocene formations of the lower Pliocene are continued by the red, yellow or brown fawn sands of the middle Pliocene. It is a series which develops mainly west of the basin where it can reach $30 \mathrm{~m}$ near Meknès. The upper Pliocene, with an average thickness of $30 \mathrm{~m}$, consists of an alternation of pulverulent clay limestones and micritic limestones considered as lacustrine.

Middle and Upper Quaternary: All the deposits show that the environment becomes truly continental (fluviatile) [2].

\subsection{The Hydrological Context}

The main rivers crossing the basin between the southern and northern boundaries are (from west to east) the El Kell Wadis (tributary of the Wadi Beht), R'Dom (the confluence of the Boufekrane and Ouislane wadis) And Mikkes. These wadis usually have an SSE-NNW direction. The wadis El Kell, R'Dom and the tributaries of the left bank of the wadi Mikkès drain the plateau of Meknes. All these wadis come from the Middle Atlasic Causse. These wadis are very deep on the plateau of Meknes (40 to 100 $\mathrm{m}$ below the structural surface), which is at the origin of numerous small sources along the valleys. The average slope of the rivers is generally between $2 \%$ and $3 \%$ in the plateau of Meknes and in the southern part of the Saïss. On the other hand, it is much lower for the Fez and N'ja wadis in the lower part of the Saïss or it does not exceed $0.5 \%$ (ABHS).

Hydrogeological framework: In the Meknes basin, two main aquifers are highlighted: The groundwater of the Plio-quaternary and the deep aquifer of the lias.

Plio-quaternary: The aquifer mainly circulates in the sand, sandstone and locally the lacustrine limestones [3]. The water surface of the water table is generally between 10 and $40 \mathrm{~m}$ deep (ABHS, 2005). To the north of the basin, the depths are weak; generally, less than $20 \mathrm{~m}$. In the south and west of the basin, the depth of the water is generally greater than $30 \mathrm{~m}$. In the center, this depth is between 25 and $35 \mathrm{~m}$. The average depth of the surface of the water table is $25 \mathrm{~m}$. The recharge of this aquifer takes place through the infiltration of rainfall, by upward drainage from deep aquifers and by the return of irrigation water. The mineralization of the water is low and remains less than $1 \mathrm{~g} / \mathrm{l}$. (ABHS, 2006).

Deep aquifer: The deep water flows mainly through the Lias. This is largely exposed in the Causse, plunges gradually under the plain by faults and flexures towards the NW, with an average slope of $6 \%$. This burial of the Lias reaches its maximum depth of about $1000 \mathrm{~m}$ in the synclinal zone bordering the pre-rif where the Lias is brutally straightened by faults to constitute the heart of the anticlines of prerifal wrinkles [3]. The feeding of this water table is done on the one hand, by lateral abutment from the Causses aquifer adjacent to the south and, on the other hand, from the rainwater and the melting snow that the calcareous outcrops of Causses of the Middle Atlas to the south. Its waters circulate from the South to the North, and are placed under a thick series of impermeable marls of the Miocene which separates the two aquifers (ABHS, 2006).

\section{Geolocation of the Study Area}

The center of Ras Jerry is located about $23 \mathrm{~km}$ southwest of the city of Meknes. It is bounded on the north by the regional road $n{ }^{\circ} 701$ which connects the city of Meknes to the commune of Ras Jerry (Figure 1).

\section{Material and Methods}

The electrical sounding allows to study the variation of the resistivity of the soil with the depth. The acquisition of the data in the field is carried out as follows: Is sent into the ground by means of two electrodes A and B, a current of intensity (I) by means of batteries or generators. The potential difference $(\Delta \mathrm{V})$ which occurs between two measuring electrodes $\mathrm{M}$ and $\mathrm{N}$ is measured by means of a potentiometer (direct reading) or a recorder, each time increasing the length of the line $\mathrm{AB}$. The values of the apparent resistivity obtained represent increasingly large depths. The Schlumberger quadrupole, which has been applied in the present study, is characterized by a small distance $\mathrm{MN}$ in front of $\mathrm{AB}$ to introduce the notion of an electric field, thus facilitating theoretical calculations. The application of the ohm law makes it possible to calculate for each line length $A B$ an apparent resistivity value (R) defined by the following formula: 


$$
R=K . \Delta V / I
$$

$\mathrm{K}$ being a coefficient which depends on the geometry of the AMNB device. Electrical methods are widely used in hydrogeology. They are based on the measurement of the resistivity of geological formations. According to the method, we distinguish between soundings, drags and electrical profiling. It is mainly to study the structure of the aquifer by profiling and geo-electric maps. This study is part of a better understanding of the surface and subsurface structure of aquifers through the acquisition of the most relevant data. The geo-electric quadripole used is the Schlumberger symmetric device. Due to the great depth of investigation desired, the spacing of the electrodes used is: $\mathrm{AB}=4000 \mathrm{~m}$,
$\mathrm{AB}=2000 \mathrm{~m}, \mathrm{AB}=1000 \mathrm{~m}$. The apparent resistivity values measured for the different $A B$ distances are represented as curves

$$
\rho_{a}=f\left(\frac{A B}{2}\right)
$$

in a bi-logarithmic coordinate system. They are interpreted manually using the abacuses [7]. The models obtained (true resistivities of the layers and their thicknesses) are refined by the inversion software WINSEV [8].

The acquisition chain consists of (Figure 2): A GeoTrade resistivity meter, a GeoTrade 600v dc generator, $1.000 \mathrm{~m}$ of cables on portable coils; Iron stakes and copper electrodes, Maintenance equipment and GPS.

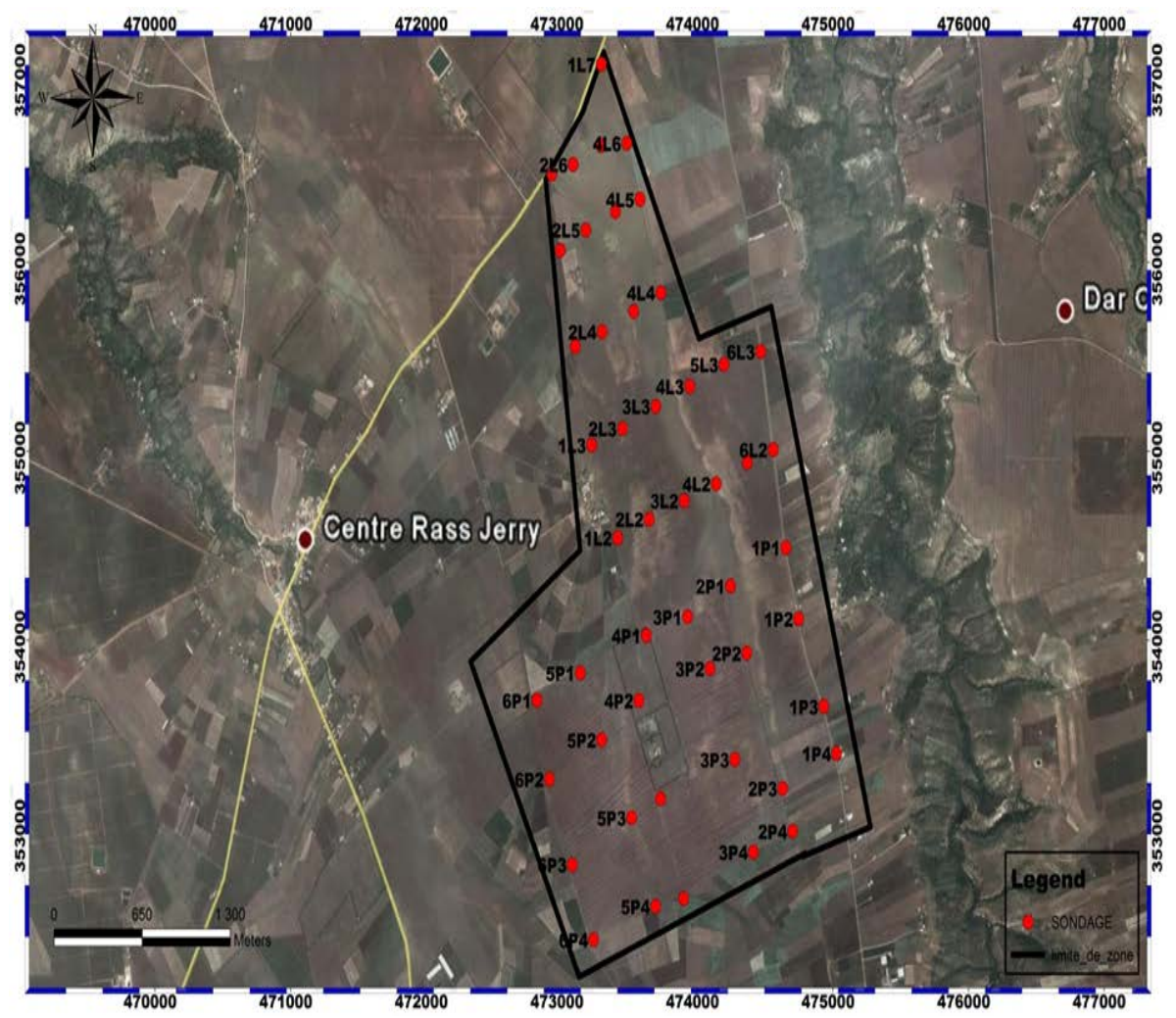

Figure 1. Implementation of the geo-electric measurements carried out at Ras Jerry

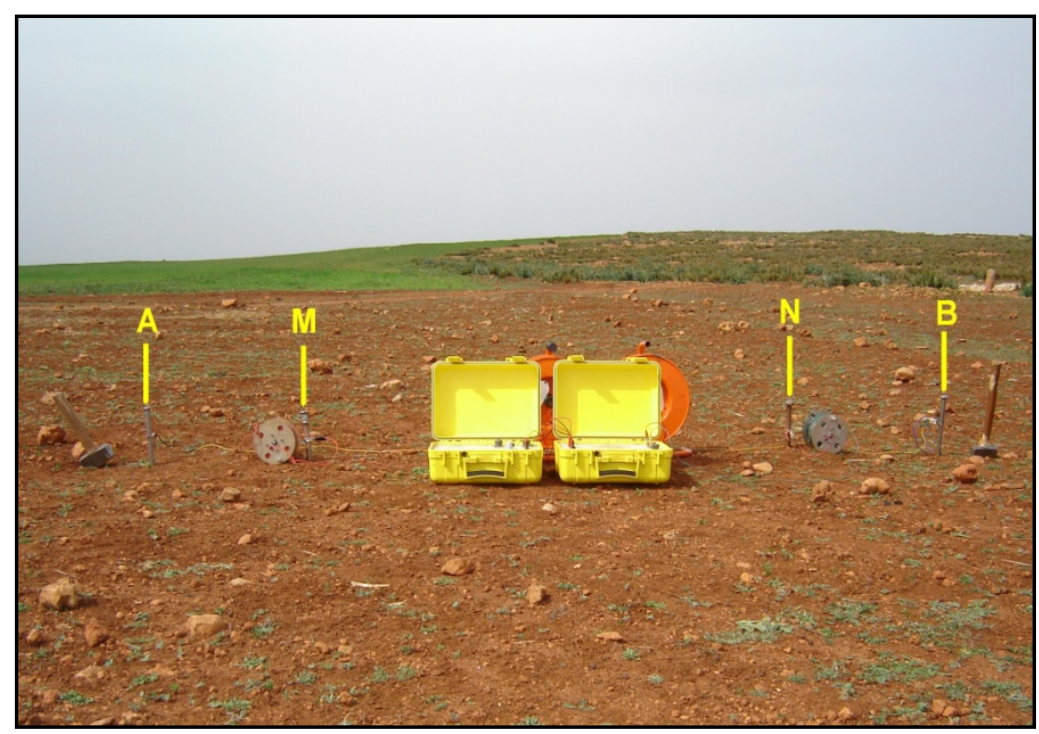

Figure 2. Equipment used 


\section{Results}

The analysis and comparison of the results of interpretation of all the diagrams of the electric probes obtained made it possible to distinguish two families of electric drillings represented by 1P1 and 3L2

Family 1: The interpretation of the diagram of this electrical sounding shows (Figure 3) from top to bottom:

- A surface resistant surface with a thickness of 114 $\mathrm{m}$. This land corresponds to the formation of the Plio-quaternary composed mainly of sand and clay sands and sandstones.

- A conductive horizon located at $114 \mathrm{~m}$ depth. This horizon is of electrical resistivity $20 \Omega . \mathrm{m}$ and of thickness $290 \mathrm{~m}$. It probably corresponds to the marls of the Miocene.

- A resistant substratum located at a depth of $404 \mathrm{~m}$.

Family 2: The curve of the electric soundings of this family (Figure 4) shows a succession of resistant and conductive level such that:

- A surface resistant ground of $18 \mathrm{~m}$ thickness. This ground corresponds to the formation of the plioquaternary composed mainly of sand and clay sands and sandstones,

- A conductive horizon located at $18 \mathrm{~m}$ depth. This horizon is of electrical resistivity $18 \Omega . \mathrm{m}$ and of thickness $75 \mathrm{~m}$. It probably corresponds to the marls of the Miocene.

- A medium resistive horizon of resistivity $80 \Omega . \mathrm{m}$ and thickness $65 \mathrm{~m}$. It would correspond to sandy marls.

- A conductive horizon of electrical resistivity $7 \Omega . \mathrm{m}$ and thickness $65 \mathrm{~m}$. It would probably be frank marls.

- A resistant substratum located at a depth of $223 \mathrm{~m}$. Its lithological nature is nevertheless poorly defined, as it may be a shale formation or formations of the limestones of the Lias.

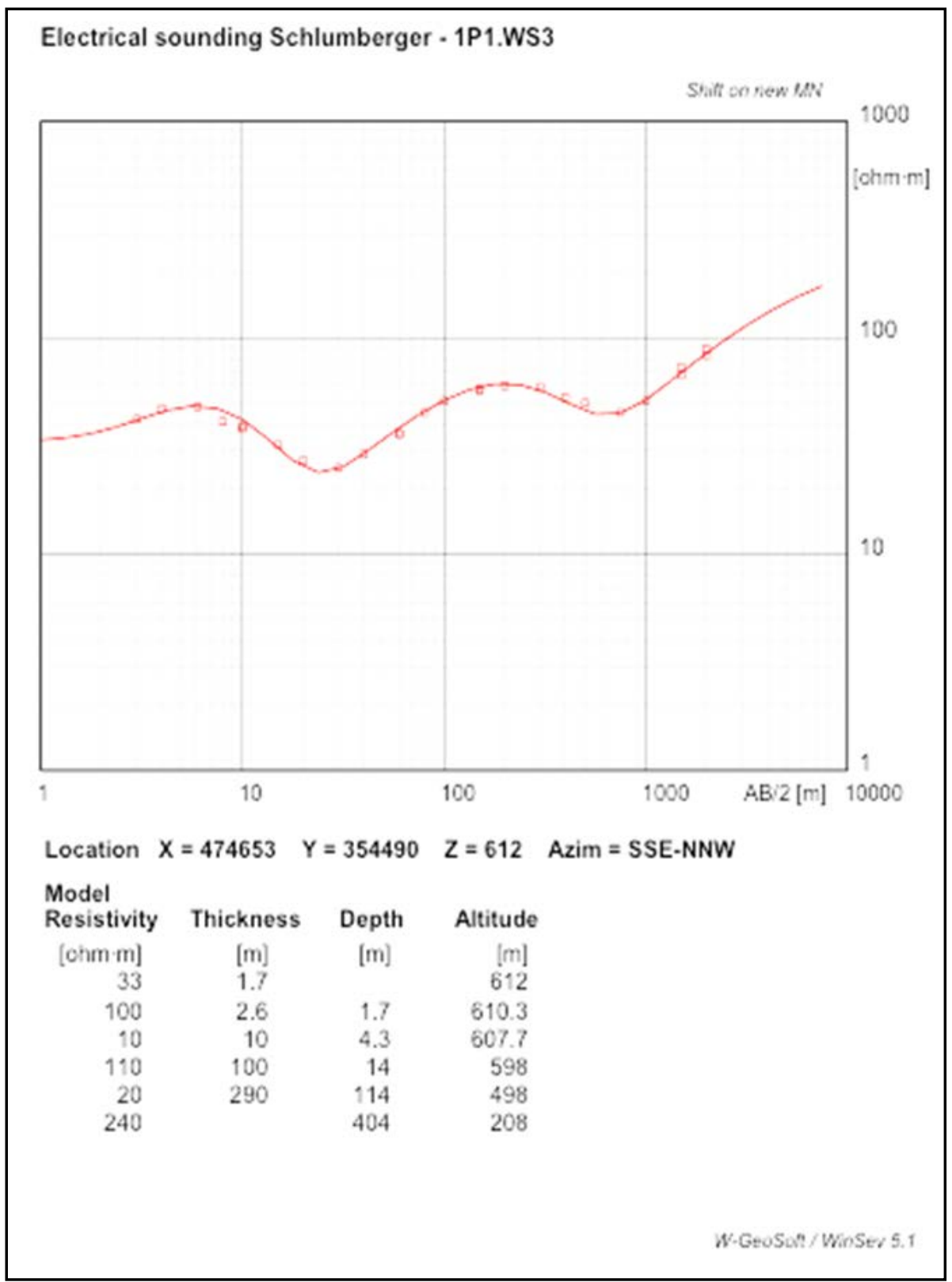

Figure 3. Family of electric soundings $n{ }^{\circ}$ 1. (A) Sand and sandstone; (B) Clay and Sand; (C) Marne; (D) Deep Resistant 
Electrical sounding Schlumberger -3P2.WS3
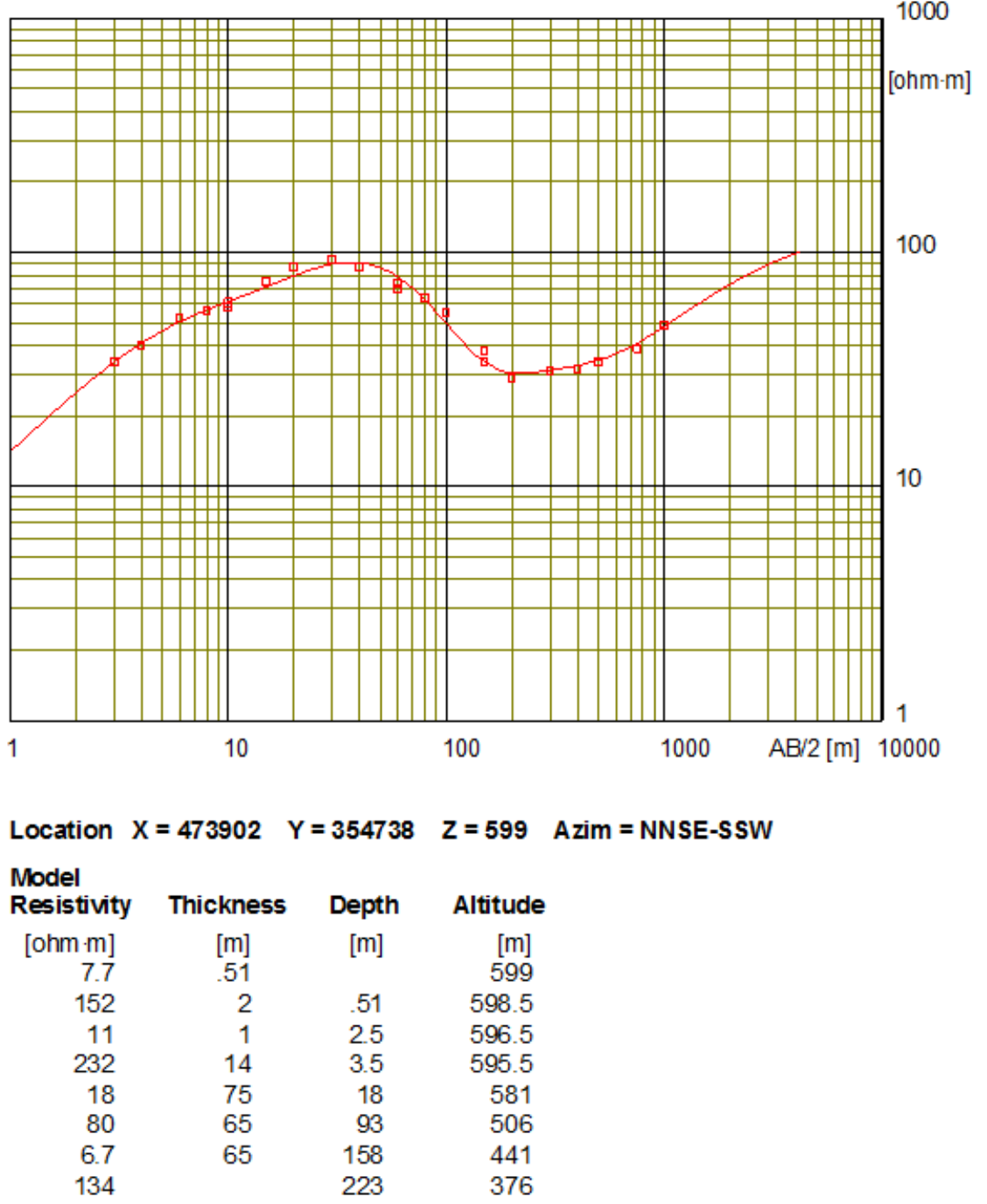

W-GeaSoft/ WinSev 5.1

Figure 4. Interpreted Diagram of the 4P3 Electrical Survey

(A) Sand and sandstone; (B) Marne (c) Deep Resistant

It should be noted that there are no drilling holes near the study area, the only deep boreholes are about $5 \mathrm{~km}$ further west and south.

\subsection{Interpretive Cards}

Based on the interpretation of the geophysical measurements obtained by the electrical soundings carried out in the study area, several interpretive maps have been developed. It is:

- Apparent isoresistivity map for a spacing $\mathrm{AB}=$ $300 \mathrm{~m}, A B=600 \mathrm{~m}$ and $A B=1000 \mathrm{~m}$ (Figure 5, Figure 6 and Figure 7)

- Map of roof isohypses of the marly conductor (Figure 8), and

- Map of the isopaques of the surface aquifer corresponding to the formations of the plio-quaternary (Figure 9)

\section{Apparent isoresistivity map}

Figure 5 shows the values of the apparent resistivity measured for a line length $A B=300 \mathrm{~m}$, in other words an investigation depth of about $50 \mathrm{~m}$. Resistive zones ( $\rho \mathrm{a} \geq$ $50 \Omega$.m): these are very broad zones that can be correlated as a rule to the fawn sands and the plio-quaternary sandstones. Conductive zone $(\rho \mathrm{a} \leq 40 \Omega . \mathrm{m})$ : these are areas of small extent which correspond to deposits of mainly clayey surface.

The resulting resistivity map (Figure 6) corresponds to the values of the apparent resistivity measured by a spacing of $A B=600 \mathrm{~m}$. That is, an investigation of about $100 \mathrm{~m}$. The analysis of the map obtained shows relatively low resistivity in the study area. Except for the South-East part at the level of the Electrical Survey 1P2 where there is the Plio-Quaternaire.

Figure 7 shows the apparent resistivity value distribution for a line length $A B=1000$. That is, an investigation of about $162 \mathrm{~m}$. Resistive zones $(\rho \mathrm{a} \geq 50 \Omega . \mathrm{m})$ : these are reduced areas in the study area. 


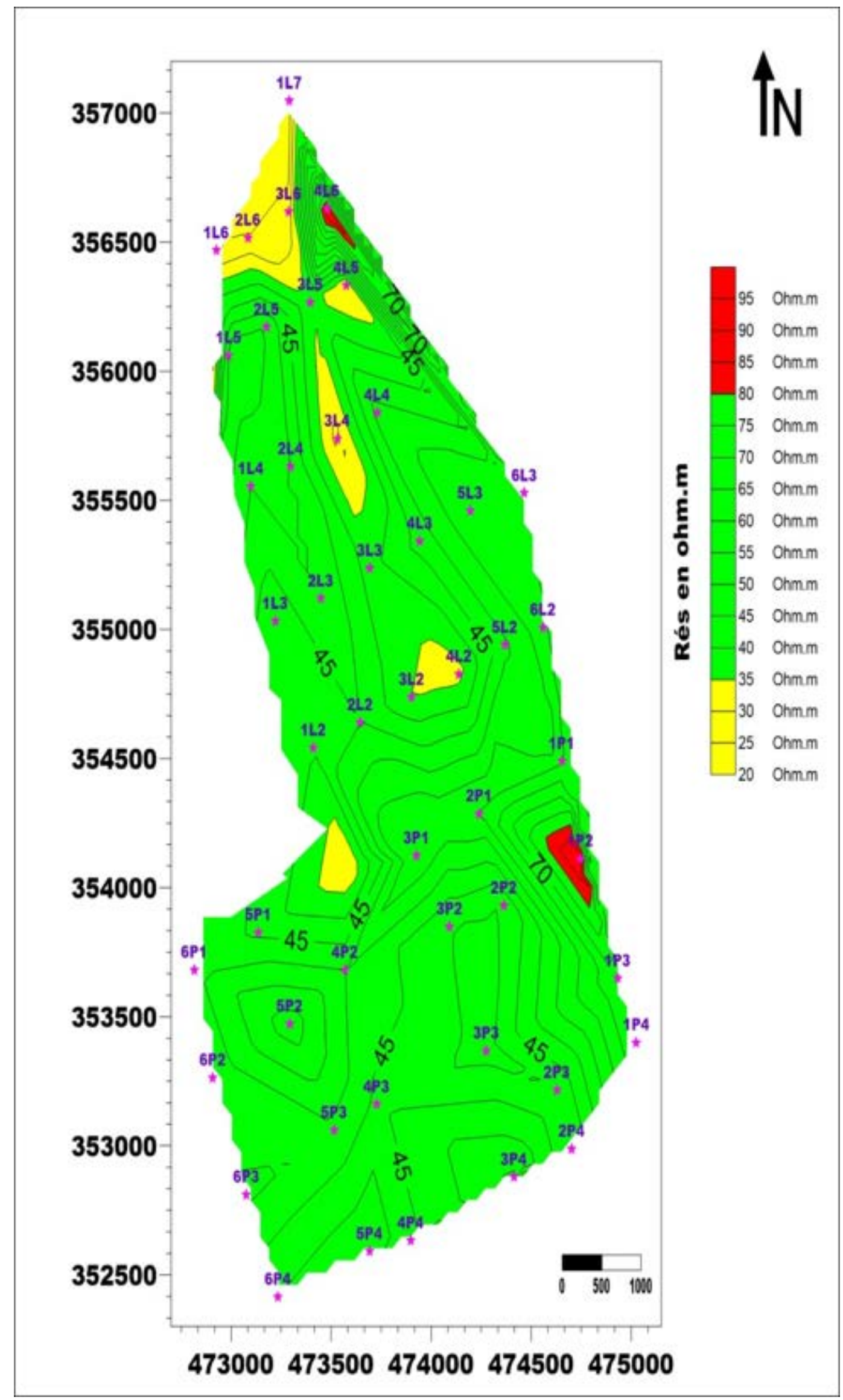

Figure 5. Apparent resistivity variation for line length $A B=300$ 


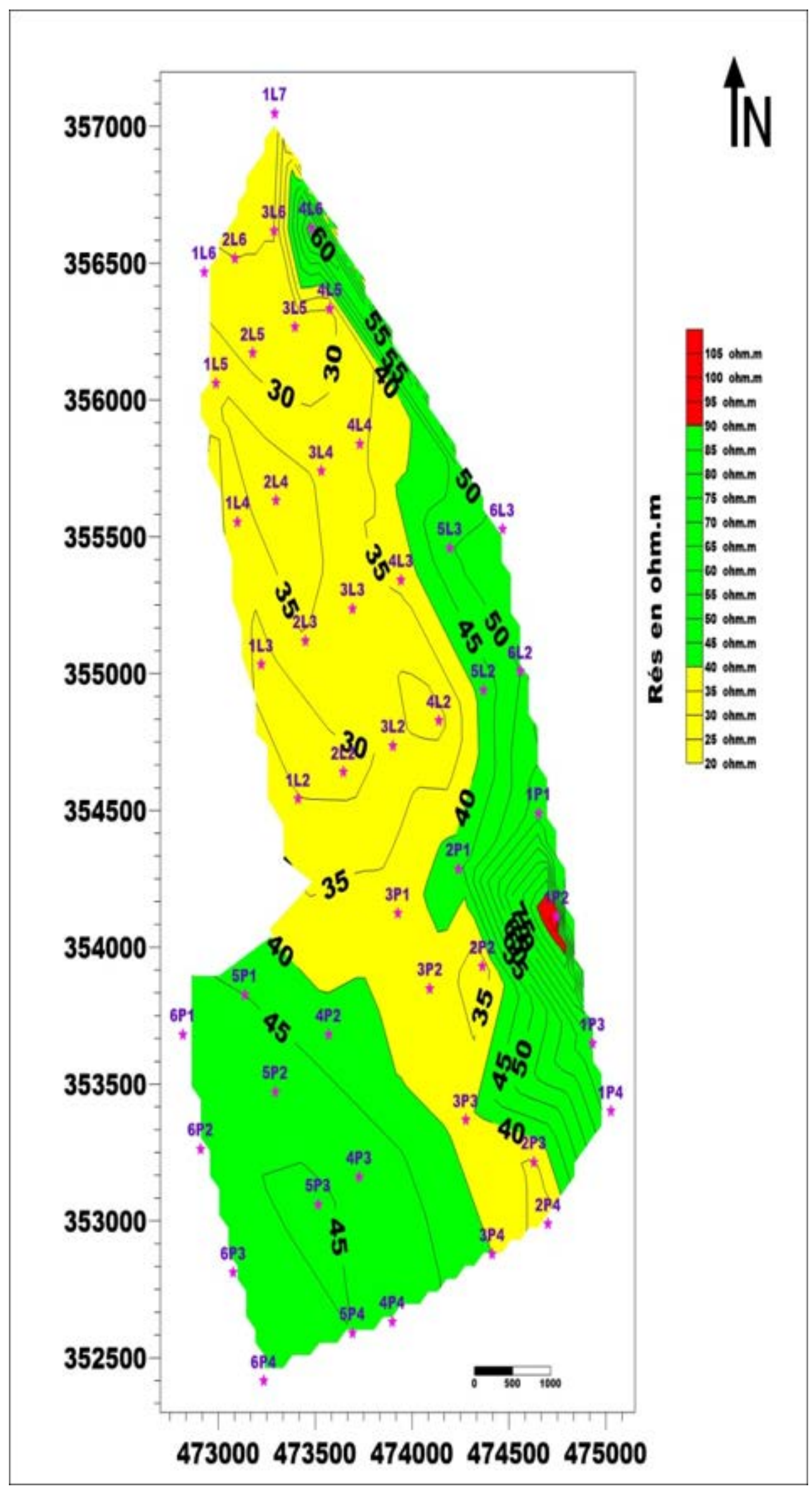

Figure 6. the apparent resistivity variation for a line length $A B=600 m$ 


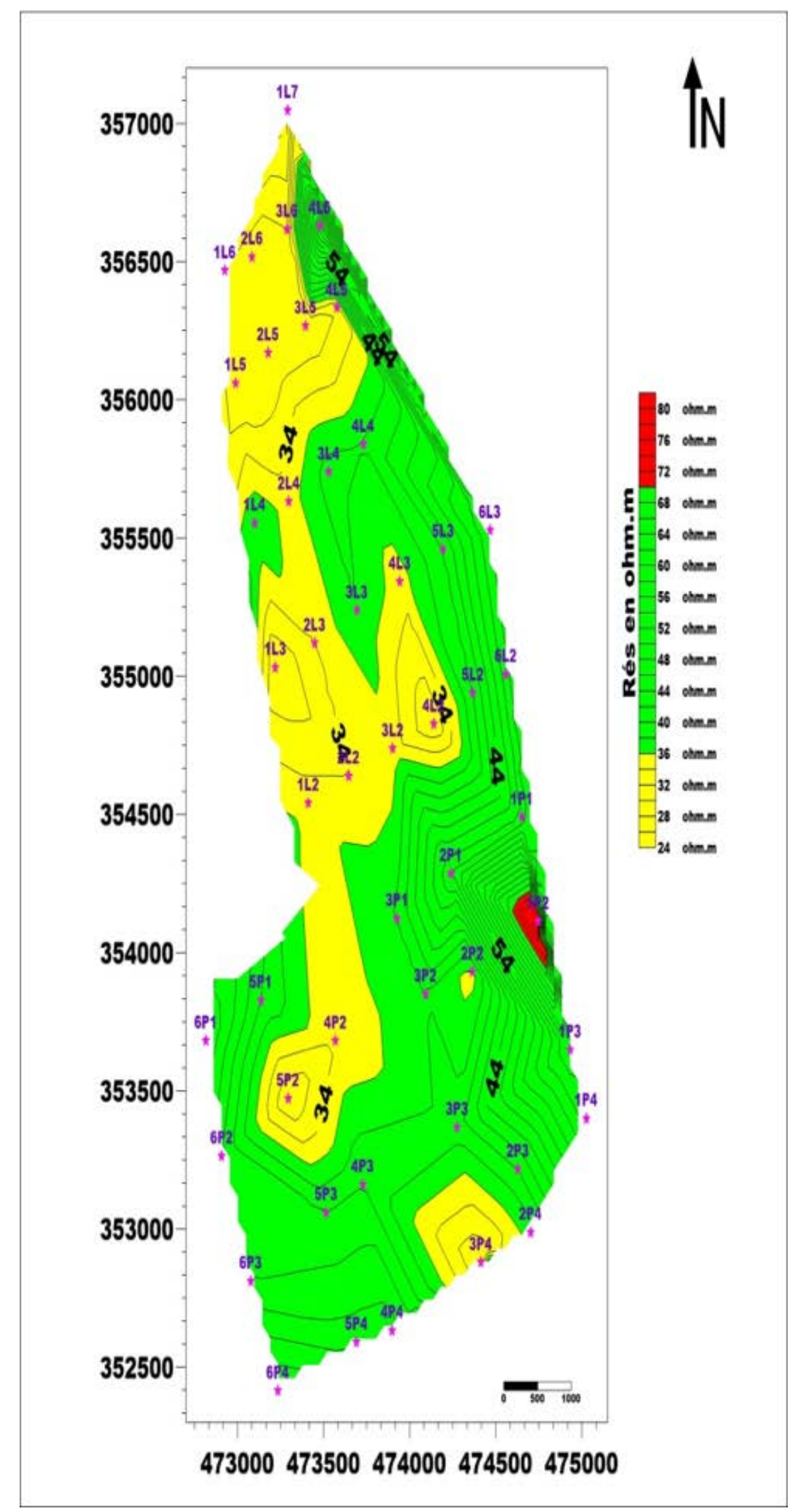

Figure 7. The apparent resistivity variation for a line length $A B=1000 \mathrm{~m}$ 


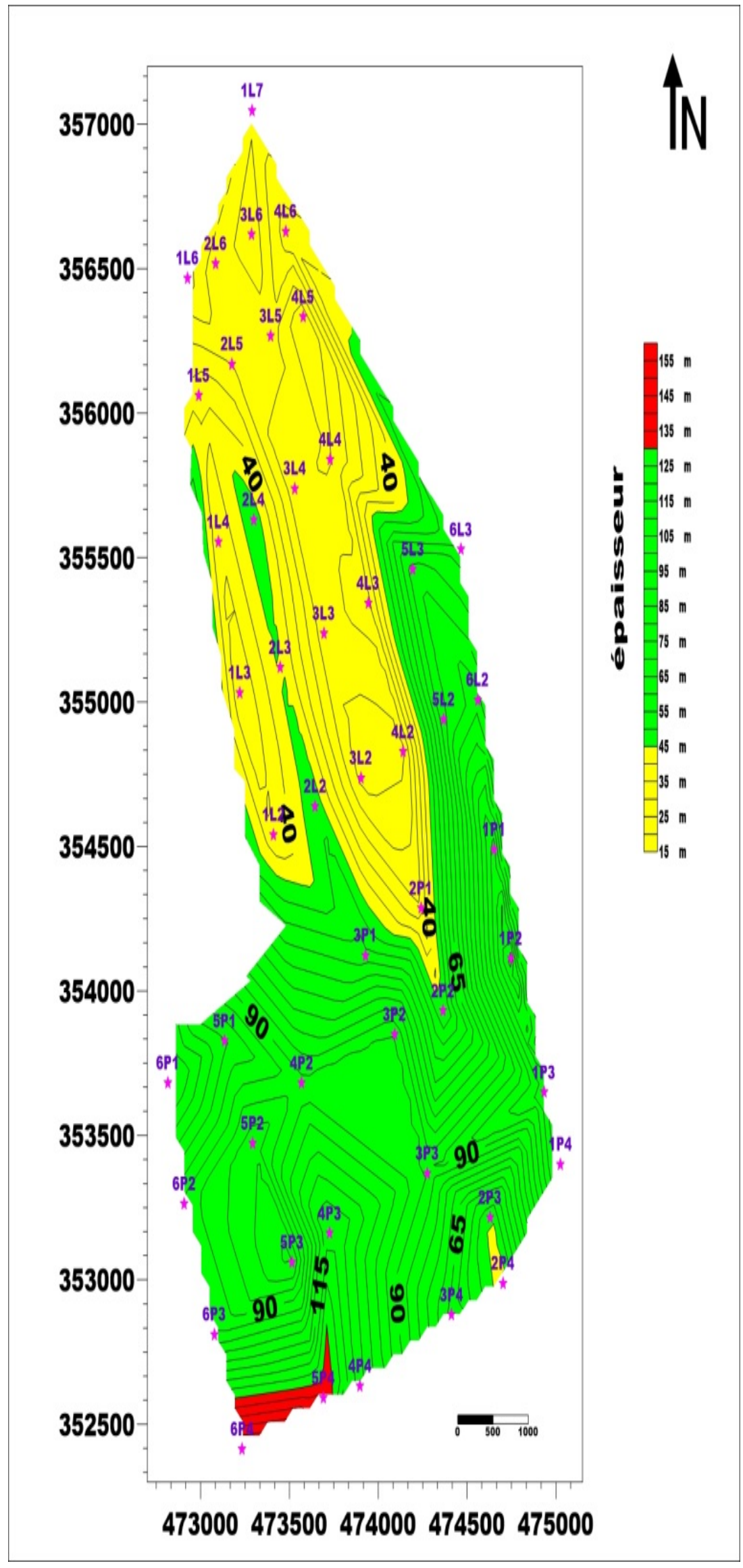

Figure 8. isopaque Map Pliocene-Quaternary cover 
Conductive zone $(\rho \mathrm{a} \leq 25 \Omega . \mathrm{m})$ : these are very wide areas. This decrease in apparent resistivity due to the existence of the marly formation.

\subsubsection{Isopaque Map of the Surface Aquifer}

The analysis of the map (Figure 8) obtained shows that there is a clear increase in the thickness of the surface aquifer in the southern direction. The greatest thickness of this aquifer is observed in the SW part, and more precisely in the electric borehole 5P4 where this thickness exceeds $120 \mathrm{~m}$.

\subsubsection{Map of Miocene Marls Isohypses}

The map of the marsh isohypses represents the altitude of the marly horizon in the Ras Jerry domain.

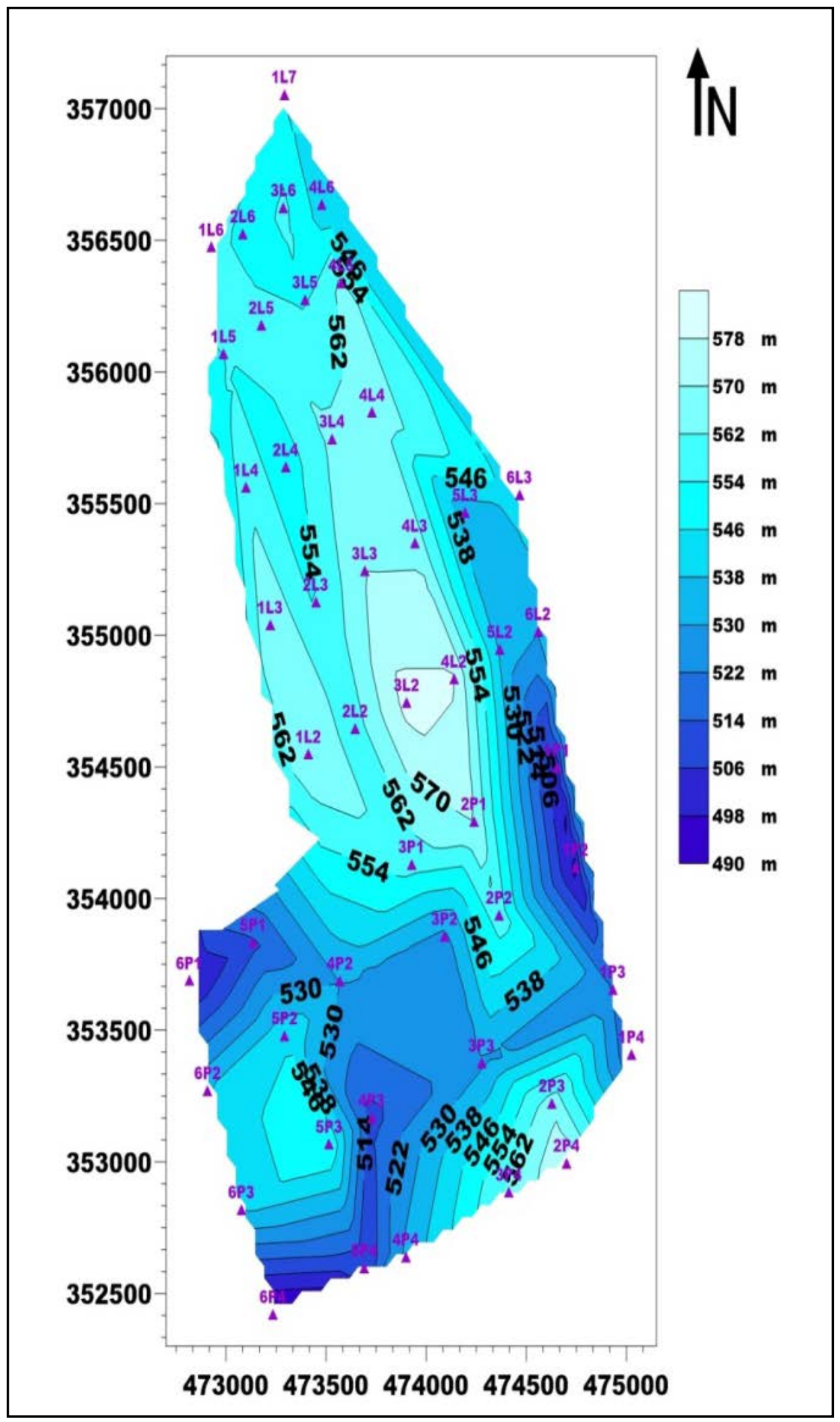

Figure 9. Marsh conductor roof isohypsis map 
The map obtained (Figure 9) shows that:

-The highest depths, corresponding to the weakest isohypses, are located in the South zone.

-The lowest depths, corresponding to the highest isohypses are observed in the northern part.

\subsection{Geo-electric Cuts}

The realization of the geo-electric sections is very important in a geo-electric study, since they can give a general view of the geological structure of the area to be prospected to arrive at a paleo-geographic structure and to fully understand all the tectonic accidents that affected the deposited terrains.
To better follow in depth, the variation of the levels of the different horizons, two transverse geo-electric sections and a longitudinal section were established.

\subsubsection{Transverse Geo-electric Section 1}

The geo-electric section (Figure 10) crosses the zone studied from WSW to ENE. This section includes the electric soundings 1P1, 2P1, 3P1, 4P1, 5P1, 6P1.

The section obtained shows significant variations in the geometry of the horizons. Indeed, one observes an important dome in the level of the electrical sounding 2P1 and two subsidence on either side of this dome especially in the electrical soundings $1 \mathrm{P} 1$ and $6 \mathrm{P} 1$. In these areas, the thicknesses become relatively large.

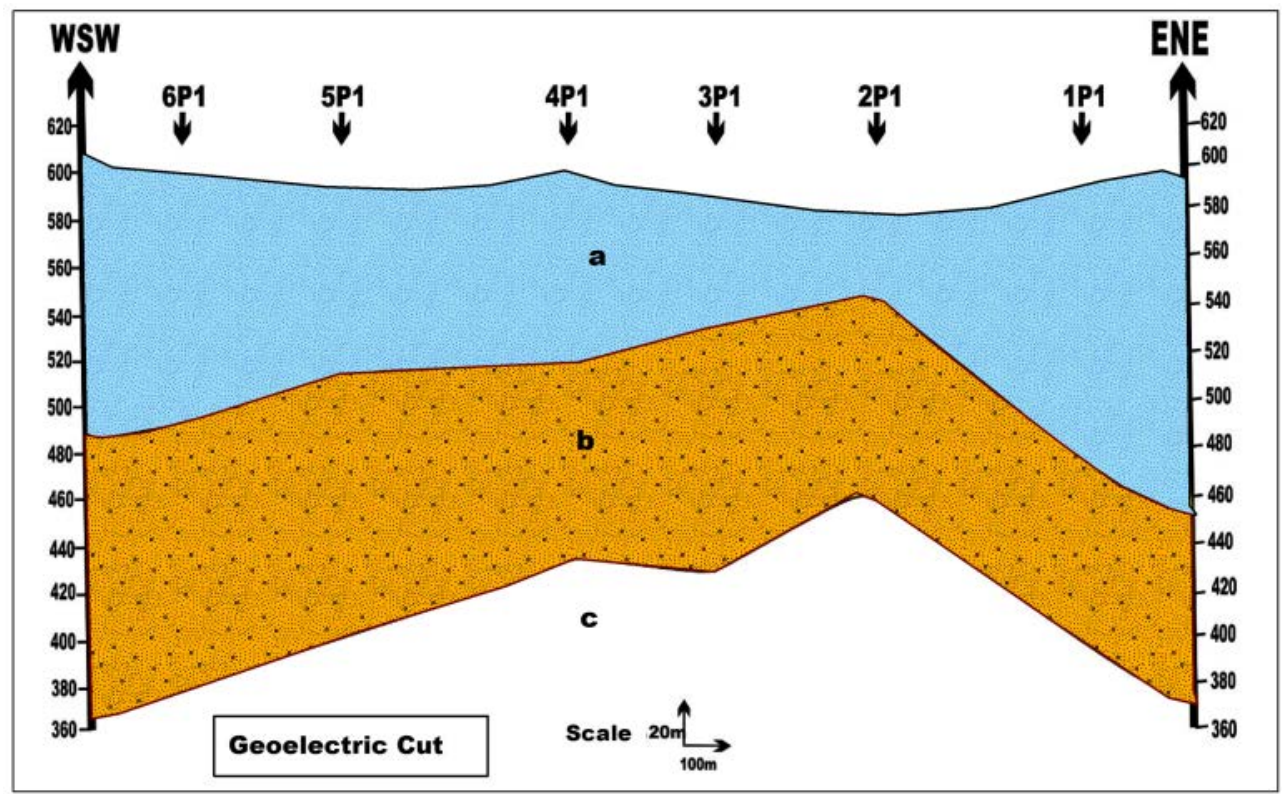

Figure 10. Geo-electric section $n^{\circ} 1$

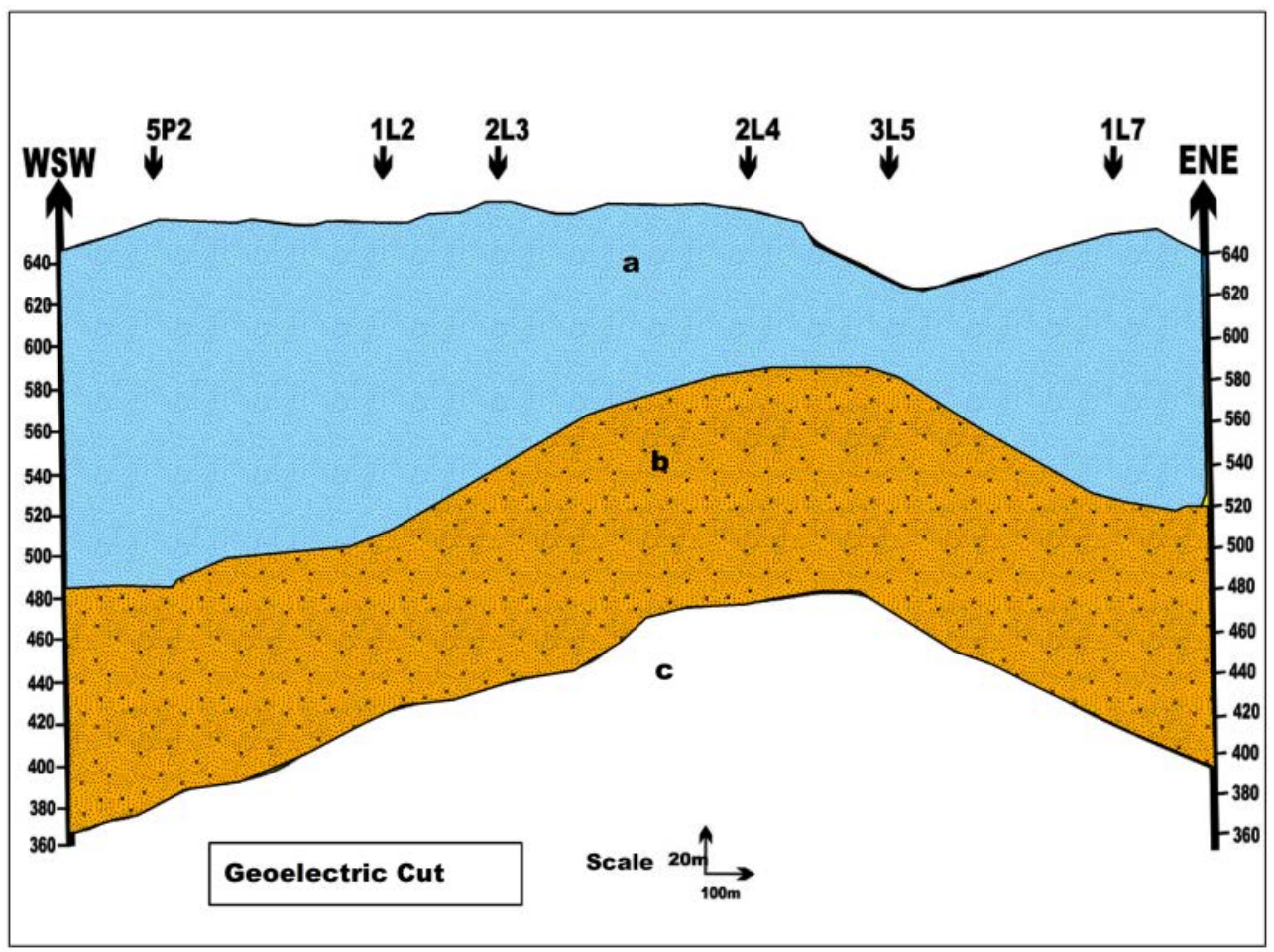

Figure 11. Geo-electric section 2 


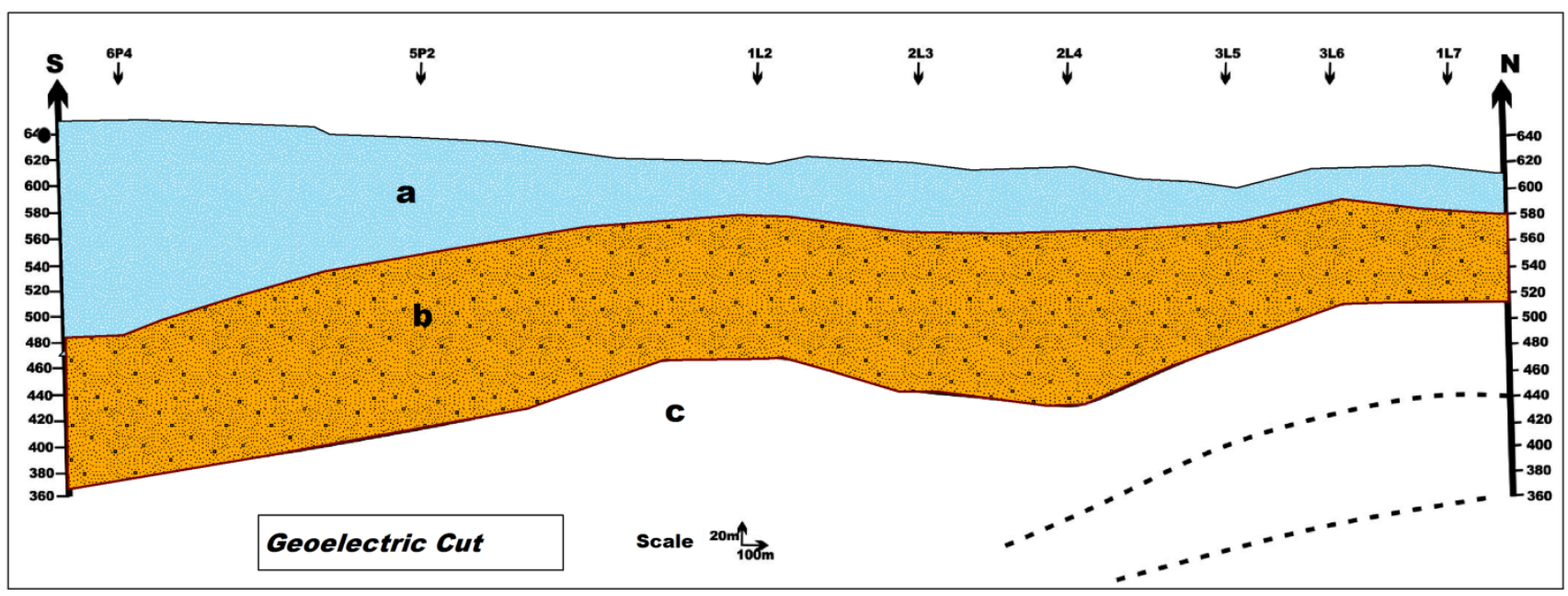

Figure 12. Geo-electric section 3

\subsubsection{Transverse Geo-electric Section 2}

The geoelectric section (Figure 11) crosses the studied area. It is oriented globally from WSW to ENE. This section includes the 6P4, 5P4, 4P4, 3P4, 2P4, 1P4 drill holes.

The section obtained shows significant variations in the geometry of the horizons. Indeed, one observes a large dome in the level of the soundings 3P4 and 2P4 and two subsidence on either side of this dome especially at the 1P4 and 6P4 electrical soundings where subsidence is important. In these areas, the thicknesses become relatively significant.

\subsubsection{Longitudinal Geo-electric Sections}

The geoelectric section (Figure 12) crosses the area studied from $\mathrm{S}$ to $\mathrm{N}$. This section includes the 6P4, 5P2, 1L2, 2L3, 2L4, 3L5, 3L6 and 1L7 electrical drill holes.

From the geo-electric section, there is a significant variation in the thickness of the layers from north to south, it is important in the South zone and low in the North zone.

There is also a very deep resistance level which corresponds either to liasic limestones or to Paleozoic schists.

\section{Discussion}

A study was constructed based on data from 153 surveys distributed throughout the Saïs basin. This study shows that the depths of the marls were divided into four classes of the same size. They range from 0 (outcrop) to $137 \mathrm{~m}$, with an average of $56 \mathrm{~m}$. The center of the basin along the Boufekrane-Haj Kaddour-Ain Taoujdate axis is the sector where plio-quaternary filling (or marl depth) is the most important. On the other hand, by approaching the pre-rifan or atlas edges, this thickness is reduced in a significant way. We can also note the great power of the Plio-Quaternaire in the West and SW of the city of Meknes.

\section{Conclusion}

The method of electrical resistivity applied to the recognition of underground aquifers is a method that can be adapted to both regional and local study projects.
Indeed, in the regional case, it allows to follow the evolution of petro-physical, geometric, etc. In addition to the fact that it makes it possible to locate zones with potential water. In the case of local prospecting, it allows at least to define the vertical succession of existing aquifers in addition to the local petro-physical characteristics that can be compared to those of the boreholes.

In the light of this hydrogeological study by geophysical prospecting using the geo-electric method (drillings and electric trails), the following important points emerge:

- $\quad$ The surface aquifer of the plio-quaternary sand and clay sands and sandstones is generalized in the study area. The thickness of this surface aquifer is variable in the field studied.

- It varies between $30 \mathrm{~m}$ in the northern part and more than $150 \mathrm{~m}$ in the southern part.

- The substratum of the surface aquifer consists of Miocene marls.

- A deep, deep geo-electric horizon has been demonstrated by deep electric soundings.

- Its lithology is not well defined and difficult to interpret because it could be either palaeozoic schists or liasic limestones.

As a recommendation, hydrogeologically interesting areas are in the southern part of the study area because the greatest thickness of the groundwater (sand and sandstones of plio-quaternary age) is in this zone.

\section{References}

[1] Cirac, P., 1987. Le bassin sud -rifain occidental au néogène supérieur. Evolution géodynamique sédimentaire et de la paléogéographie au cours d'une phase de comblement. $\mathrm{PhD}$ thesis. Bordeaux 1 University. France. 287 p.

[2] Amraoui, F., 2005. Contribution à la reconnaissance des aquifères karstique, cas du Lias de la plaine de sais et du causse moyen atlasique tabulaire (Maroc), $\mathrm{PhD}$ thesis. Hassan ii Ain Chock University. Casablanca- Morocco, 27p. 100p. 123 p.

[3] Essaahlaoui, A., 2000. Contribution à la reconnaissance des formations aquifères dans le bassin de sais (Maroc): prospection géoélectrique, étude hydrogéologique et inventaire des ressources en eau. PhD thesis in Applied sciences. Emie. Rabat- Morocco. $250 \mathrm{p}$.

[4] Kenafi, J., 2002. Evolution structural méso-cénozoique des Rides périfaines (Maroc): Halocinèse. Géométrie et reconstitution 
géodynamique. Apport de données de sismique réflxión et de forages pétroliers. PhD thesis. University of Kenitra. Morocco.

[5] Harmouzi, O., 2010. Reconnaissance détaillée de la partie nord-est du Bassin de Saïss (MAROC): interprétation de sondages électriques verticaux par combinaison des méthodes statistique, géostatistique et d'inversion. $\mathrm{PhD}$ thesis. Bordeaux 1 University and Moulay Ismail University. France. 8-15 p.
[6] Wernli, R., 1987. Notes de Mémoire Service Géologique du Maroc, 33, 1-266

[7] Mayer de Stadelhofen, C. 1991. . Applications de la géophysique aux recherches d'eau. Technique et Documentation-Lavoisier. France.

[8] Jenny, J. Borreguerro, M., 1993. WINSEV, programme d'interprétation des sondages électriques verticaux réalisés selon le dispositif Schlumberger. 